\title{
Insect Pests of Mustard and their Natural Enemies in Assam
}

\author{
P. P. Pradhan*, R. N. Borkakati and D. K. Saikia \\ AICRP on Biological Control, AAU, Jorhat Centre, Department of Entomology, Assam \\ Agricultural University, Jorhat-785 013, India \\ *Corresponding author
}

\section{A B S T R A C T}

\begin{tabular}{|l|}
\hline Ke y w o r d s \\
Mustard, Insect \\
pests, Natural \\
enemies, Predator, \\
Coccinellids
\end{tabular}

Field experiment was conducted in Instructional-Cum-Research (ICR) farm, Assam Agricultural University, Jorhat during rabi 2018\& 2019 to investigate the insect pests and natural enemies of mustard. During the period of present investigation, a total number of four insect pests from four different families viz, mustard aphid, Lipaphis erysimi (Kalt.); mustard sawfly, Athalialugens proxima (Klug); Flea beetle, Phyllotreta Cruciferae (Goeze); cabbage butterfly, Pieris brassicae (Linn.) were recorded at different stages of mustard crop. On the other hand, total three predators viz, coccinellid beetle (Coccinella transversalis (Fab.) and Harmonia axyridis (Fab.), green lacewing, Chrysoperla carnea (Stephens); syrphid fly, Xanthogrammas cutellaris (Fab.) and one aphid parasitoid, Diaeretiella rapae (M'lntosh) were recorded as major natural enemies on insect pests of mustard. However, out of both coccinellids $C$. transversalis was dominant and considered as major predator of aphids.

\section{Introduction}

Oilseed crops play a vital role in Indian agricultural economy. Mustard, Brassica juncea L. is one of the first domesticated oilseed crops amongst all the plants under family Cruciferae. Rapeseed \&mustard (Brassica spp.) is cultivated throughout India in spite of diverse agro-climatic conditions ranging from north-eastern/north-western hills to down south under irrigated/rainfed, timely/late sown, saline soils and mixed cropping over an area of 5.96 million hectare with a production of 8.32 million tones and productivity of $1397 \mathrm{~kg} / \mathrm{ha}$ in 2017-18 in India. Assam records 0.29 million hectare of area with an annual production of 0.19 million tonnes which gives an annual yield about $669 \mathrm{~kg} / \mathrm{ha}$ (Anonymous, 2018).

Among the various factors responsible for the low yield of mustard, damage inflicted by various insect pests is an important factor. Study of different insect pests are very essential to develop future transgenic plant of cruciferous vegetable (Shelton et al., 2009). Rai, 1976 enlisted a total of 24 species of key insect pests of mustard and rapeseed crop in India which responsible for severe infestation in different stages of crop. Further, Purwar et al., 2004 recorded more than 43 species of insect pests of rapeseed-mustard crop in India, 
out of which, the mustard aphid, Lipaphis erysimi (Kalt), the mustard saw fly, Athalialugens proxima (Klug), the painted bug, Bagrada hilaris (Burmeister) and the leaf miner, Phytomyza horticola (Goureau) are considered as major pests of mustard. Among these, the mustard aphid, L. erysimi (Kalt) has been mentioned as the most important insect pest infesting the crop right from seedling stage to maturity causing up to 96\% yield losses (Singh and Sachan, 1994; Sharma and Kashyap, 1998; Singh and Sharma, 2002). Mustard sawfly, $A$. lugensproxima Klug has become a serious pest of mustard and radish in several regions of India, including the north-east India (Narayanan and Gopalakrishnan, 2003; Chowdhury, 2009). It is a pest of cold weather and is generally active during October to March. Mustard sawfly attacks the crop at early growth period when the seedlings are 3-4 weeks old (Bogawat, 1967; Sehgal et al., 1975; Verma and Sachan, 1997; Pradhan et al., 2020a). In some situations, complete reduction in yield may be observed due to attack of $A$. proximaalone but on an average, reduction is about 25\% (Sachan, 1990). However, in a blance agro ecosystem, a number of useful biocontrol agents always present to maintain equilibrium and out of those a few entomopathogenic fungi are very much effective for management of insect pests of mustard (Pradhan et al., 2020b). Natural enemies like Chrysoperla Spp. and lady bird beetles, $C$. septempunctata appear at the later stage of crop when most of the damage has been caused by aphids in mustard. Moreover, populations of these two natural enemies are too low to reduce numbers of aphids (Aslam and Razaq, 1989).

\section{Materials and Methods}

The present investigation was conducted to study the diversity of insect pests of Brassica campestris var. toria (TS-38) and their natural enemies. A suitable and uniform site situated at $26^{\circ} 45^{\prime}$ latitude and $94^{\circ} 12^{\prime} \mathrm{E}$ longitude at an altitude of $87 \mathrm{~m}$ above mean sea level. An area of $500 \mathrm{~m}^{2}$ was raised as per recommendation of Package of Practice of Assam Agricultural University, Jorhat except plant protection measure for the survey and the investigation. There were 10 subplots of $1 \mathrm{~m}^{2}$ size selected randomly. Observations on incidence of mustard aphid and its natural enemies were recorded on $10 \mathrm{~cm}$ apical twig at weekly interval by selecting 10 plants randomly from each subplot. Further, to assess the population of other pests including mustard sawfly and flea beetle 10 plants were selected from each subplot and the population of the insects were counted visually in situ at weekly interval.

Monitoring of the incidence of insect pests and their natural enemies was carried out along with collection of adult arthropods through sweep net method, and adopting the methods suggested by Reissig et al., (1986) and Bayot et al., (1990). Direct count method of arthropods by visual observation was also carried out as and when necessary. The arthropods were sorted out under stereozoom binocular microscope, separated, counted, and identified up to species/genus/family level with available keys and literature. To study the feeding potential of adult ladybird beetles, 10 numbers of coccinelids were kept in petri dishes containing 500 numbers of aphids and then predatory efficiency observed after $24 \mathrm{hr}$.

\section{Results and Discussion}

During the period of present investigation, a total number of four insect pests (Table 1.\& Fig. 1-3.) were recorded at different stages of mustard under different orders and different families viz, mustard aphid, L.erysimi (Kalt.); mustard sawfly, A.lugensproxima (Klug);flea beetle, P.Cruciferae (Goeze); cabbage butterfly, P. brassicae (Linn.). 
Table.1 Insect pest complex associated with mustard

\begin{tabular}{|c|c|c|c|c|}
\hline Common name & Scientific name & Order: Family & Feeding site & Status \\
\hline Mustard aphid & Lipaphis erysimi(Kalt.) & Hemiptera: Aphididae & Leaf & +++ \\
\hline Mustard sawfly & Athalialugens proxima (Klug) & $\begin{array}{c}\text { Hymenoptera: } \\
\text { Tenthredinidae }\end{array}$ & Leaf & +++ \\
\hline Cabbage butterfly & Pieris brassicae (Linn.) & Lepidoptera: Pieridae & Leaf & +++ \\
\hline Flea beetle & Phyllotreta cruciferae (Goeze) & $\begin{array}{c}\text { Coleoptera: } \\
\text { Chrysomelidae }\end{array}$ & Leaf & + \\
\hline
\end{tabular}

+ observed 1 or 2 times/ +++ observed frequently almost all time

Table.2 List of natural enemies (predators) of insect pests of mustard

\begin{tabular}{|c|c|c|c|c|}
\hline Species & Order & Family & Prey & Prey stage \\
\hline Coccinella transversalis (Fab.) & Coleoptera & Coccinellidae & L. erysimi & Nymph and adult \\
\hline Harmonia axyridis (Fab.) & Coleoptera & Coccinellidae & L. erysimi & Nymph and adult \\
\hline Chrysoperla carnea (Stephens) & Neuroptera & Chrysopidae & L. erysimi & Nymph and adult \\
\hline Xanthogrammascutellaris (Fab.) & Diptera & Syrphidae & L. erysimi & Nymph and adult \\
\hline Diaeretiella rapae (M'Intosh) & Hymenoptera & Braconidae & L. erysimi & Nymph and adult \\
\hline
\end{tabular}

Fig.1-8 Adult of Lipaphis erysimi (1) Larva of Athalialugens proxima (2) Adult of Phyllotreta cruciferae (3) Adult of Diaeretiella rapae(4) Larva of Coccinella transversalis (5) Adult of Coccinella transversalis (6) Adult of Harmonia axyridis(7) Eggs of Chrysoperla carnea (8)

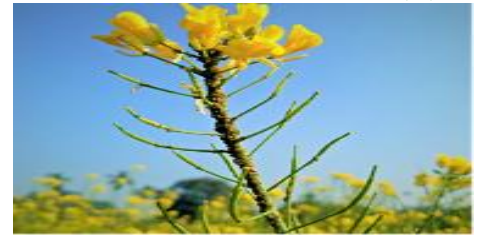

1

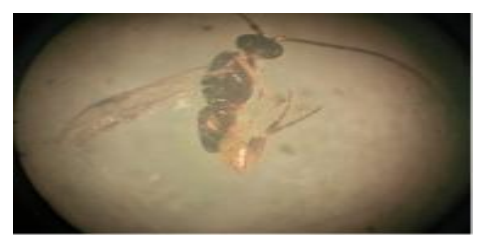

4

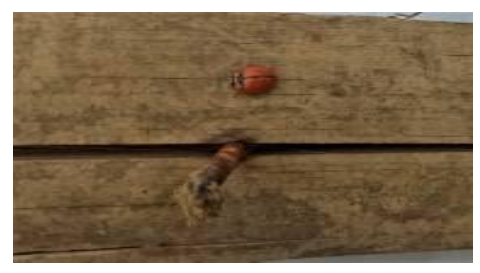

7

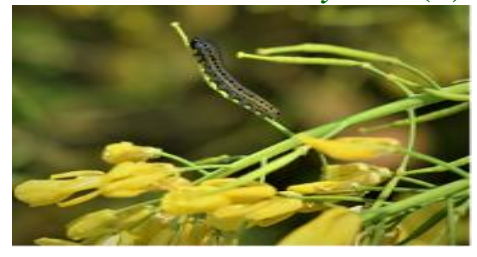

2

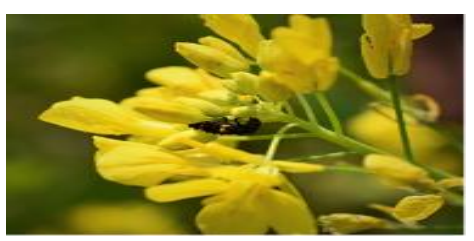

5

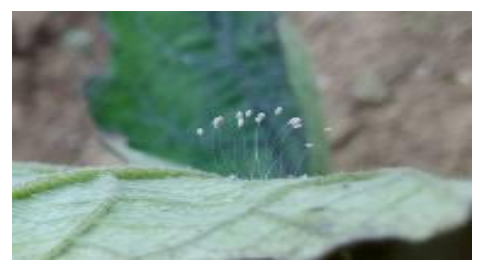

8

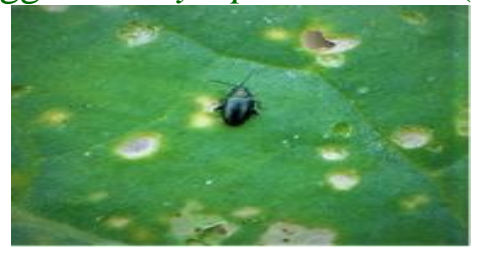

3

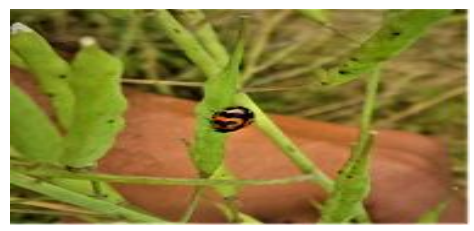

6
Among these four insect pests, mustard aphid, mustard sawfly and cabbage butterfly were more destructive and considered as major insect pests of mustard whereas the flea beetle 
was occurred in a negligible manner and considered as the minor pest of mustard. In present investigation, among different insect pests associated with mustard crop, L. erysimi showed the highest occurrence followed by $A$. lugensproxima. Moreover, the major insect pests were observed frequently during each observation period, but minors were observed only one or two times. During the course of investigation, total three predators (Table $2 \&$ Fig. 4-8.) viz, occinellid beetle, green lacewing, Chrysoperla carnea (Stephens); syrphid fly, Xanthogrammas cutellaris (Fab.) and one aphid parasitoid, Diaeretiella rapae (M'lntosh) were recorded as major natural enemies on insect pests of mustard. However, two species of coccinellid predators viz, Coccinella transversalis (Fab.) and Harmonia axyridis (Fab.) were observed out of which, C. transversalis was dominant and considered as major predator of aphids.

Several studied have shown that different insect pests infest rapeseed-mustard at different locations in India. Rai, 1976 reported a total of 24 insect pests from India, whereas Bakhetia and Sekhon, 1989 recorded 38 numbers of insect pests. Manzar et al., 1998observed that only the predatory coccinellid Coccinella spp. had a regulatory effect on L. erysimi. A survey made by Singh et al., 2000 to record the coccinellid predators associated with mustard aphid, L. erysimi infesting mustard crop revealed that four species of coccinellidsviz, C. septempunctata, $C$. transversalius, $C$. sexmaculata and $B$. suturalis were present. Among these, $C$. septempunctata and $C$. transversalis were important aphidiphagous coccinellid predators of the mustard aphid. The predator species such as green lace wing (C. carnea), eleven spotted ladybird beetle (C. undecimpunctata) and seven spotted ladybird beetle $(C$. septempunctata) were recorded when the pest population of aphids was sufficiently developed on the rape cultivars (Talpur and Khuhro, 2004). Kumar et al., 1988revealed that number of syrphid species active on the crop was influenced by the level infestation by L. erysimi, Myzuspersicae and Brevicoryne brassicae. Ohiman and Kumar, 1986 reported D. rapae as an important parasitoid of $L$. erysimi in India and found it plays significant role in biological control of $L$. erysimi. Kakakhel et al., 1998reportedD. rapae as an endoparasitoid of the turnip aphid L. erysimi with a wide geographical distribution. Raj and Lakhanpal, 1998 studied the efficacy of $D$. rapae on $L$. erysimi and found that the parasitism rate was $31.69 \%$ and parasitoid host ratio was about 1:5.6. Nevertheless, from the study conducted by Begam et al., 2016 revealed that Coccinella transversalis and Micraspis discolor were the most dominant predator species observed throughout the cropping season of BhutJalakia. Interestingly, while the number of Coccinellids increases leads to maximum quantity of cabbage yield, which is also an important cruciferous vegetable (Pradhan et al., 2020a; Borkakati et al., 2018; Borkakati et al., 2019).

In conclusion from the present investigation it can be concluded that the mustard aphid, mustard sawfly, flea beetle and cabbage butterfly were key pests of mustard found abundantly at different developing stages of the crop. Fortunately a number of natural enemies of these pests also present along with them. These beneficial biocontrol agents are useful for pest suppression in an ecologically viable and sustainable pest management programmre. These biocontrol agents helps in reduction of various problems like environment pollution, development of pest resistance against insecticides, pest outbreak, pest resurgence and unacceptable higher level of pesticide residue on the crop besides human health risk. Moreover, due to untimely rain and climate change may be the reason for less encounter of insect pests and other arthropods in the field during the time of investigation. 


\section{Acknowledgement}

The authors are grateful to the Director of NBAIR, Bangaluru for the necessary funding for the experiment. The authors are also indebted to the Director of Research (Agri), Assam Agricultural University, Jorhat-785 013 for their help and suggestion during the course of the investigation.

\section{References}

Anonymous. 2018. Agricultural Statistics at a Glance. Ministry of Agriculture \& Farmers Welfare, Department of Agriculture, Cooperation \& Farmers Welfare Directorate of Economics \& Statistics. pp. 110-112.

Aslam, M., Razaq, M. 2007.Arthropod fauna of Brassica napus and Brassica juncea from Southern Punjab (Pakistan).Journal of Agricultural Urban Entomology, 24: 49-50.

Bakhetia, R. C., Sekhon, B. S. 1989. Insect pests and their management in rapeseed mustard. Journal of Oilseed Research, 6(2): 269-299.

Begam, N., Saikia, D. K., Borkakati, R. N. 2016. Seasonal incidence of major insect-pests and their natural enemies of BhutJolokia. Annals of Plant Protection Sciences, 24(2): 259-264.

Bogawat, J. K. 1967. Biology of mustard sawfly on different host plants.Indian Journal of Entomology, 29: 270-274.

Borkakati, R.N., Saikia, D.K.,Sarma, D. 2019. Manipulation of crop habitat to encourage natural enemies against key pests of cabbage ecosystem. Journal of entomology and zoology studies,7(3): 151-54.

Borkakati, R. N., Saikia, D. K., Buragohain, P. 2018. Natural enemy fauna of agrihorti ecosystem of Assam. Indian Journal of Entomology, 80(3): 658-661.

Chowdhury, M. 2009. Incidence of saw fly,
Athalialugens proxima Klug as influenced by level of irrigation and fertilizers on mustard.Journal of Plant Protection Science, 1: 80-82.

Kakakhel, S. A., Ahmed, K., Anjad, M., Hussain, S. A. 1998. The side effects of pesticides on Diaeretiella rapae, a parasitoid of the turnip aphid (Lipaphis erysimi).Anzeiger fur Schadligskunde, Ptlanzenschutz, Umwettschulz 71: 6163.

Kumar, A., Kapoor, V. C., Mahal, M. S. 1988. Population buildup and dispersion of immature stages of aphid phagous syrphids (Syrphidae: Diptera) on raya Brassica junceaCoss. Journal of Insect Science, 1:39-48.

Manzar, A., Lal, M. N., Singh, S. S. 1998. Correlation between incidence of insect pests on Brassicae species and ecological parameters. Shashpa, 5: 171174.

Narayanan, K., Gopalakrishnan, C. 2003. Evaluation of entomopathogenic nematode, Steinernema feltiae against field population of mustard sawfly, Athalialugens proxima (Klug) on radish.Indian Journal of Experimental Biology, 41: 376-378.

Pradhan, P.P., Borkakati, R.N.,Saikia, D.K. 2020a. Bio efficacy of certain entomopathogenic fungus against major insect pests of Brassica campestris var.Toria.Journal of entomology and zoology studies, 8(1): 840-843.

Pradhan, P.P., Borkakati, R. N., Saikia, D.K. 2020b. Seasonal incidence of insect pests and natural enemies of mustard in relation to meteorological parameters. Journal of entomology and zoology studies, 8(1): 1538-1542.

Purwar, J. P., Singh, R. K., Mall, P. 2004. Eco-friendly management of insect pests in rapeseed-mustard. Indian Farmers Digest, 37(10): 34-35.

Rai, B. K. 1976. Pests of oilseed crops in 
India and their control. ICAR, New Delhi, p. 121.

Raj, D., Lakhanpal, G. C. 1998. Efficacy of endoparasitoid, Diaeretiella rapae on aphid complex infesting rapeseed in mid hill zone of Himachal Pradesh. Indian Journal of Entomology Research,22: 245-251.

Sachan, G. C. 1990. Insect pest problem in Brassica and research work at Pantnagar, Paper presented at second Brassica subnet work meeting sponsored by DRC Canada held on January 4-6, 1986 at G.B.P.U.A.T., Pantnagar, India.

Sehgal, V. K., Bhattacharya, A. K., Singh, K. N. 1975. Food preference of mustard sawfly grubs, Athalia proxima Klug. (Hymenoptera: Tenthredinidae). Scientific Culture, 41(9): 430-433.

Sharma, P. K., Kashyap, N. P. 1998. Estimation of losses in three different oil seed Brassica crops due to aphid complex in Himachal Pradesh (India).Journal of Entomological Research, 22: 22-25.

Shelton, A. M., Gujar, G. T., Chen, M., Rauf, A., Srinivasan, R., Kalia, V., Mittal, A., Kumari, A., Ramesh, K., Borkakati, R., Zhao, J. Z., Endersby, N., Russell, D. A., Wu, Y. D., Uijtewaal, B. 2009.Assessing the susceptibility of cruciferous Lepidoptera to Cry1Ba2 and Cry1Ca4 for future transgenic cruciferous vegetables. Journal Economic Entomology, 102(6): 22172223.

Singh, C. P., Sachan, G. C. 1994. Assessment of yield losses in yellow sarson due to mustard aphid, Lipaphis erysimiKalt.Journal of Oilseed Research, 11(2): 179-184.

Singh, N. N., Rai, S., Rai, S. 2000. Relative abundance of different coccinellids in mustard ecosystems. Indian Journal of Entomology, 62: 422-426.

Singh, Y. P., Sharma, K. C. 2002. Integrated approach to manage the mustard aphid Lipaphis erysimi (Kaltenbach) (Homoptera: Aphididae) in oilseed Brassica crops- a review. Journal of Amphibiology, 16: 77-78.

Talpur, M. A., Khuhro, R. D. 2004. Relative occurrence and abundance of mustard aphid, Lipaphis erysimi (Kalt.) and their predators on Rainbow and Oscar canola varieties. Journal of Asia Pacific Entomology,7(2): 215-219.

Verma, R. K., Sachan, G. C. 1997. Impact of sowing time on the occurrence of Athalia proxima Klug on three Brassica cultivars.Annals of Plant Protection Sciences, 5(1): 44-47.

\section{How to cite this article:}

Pradhan, P. P., R. N. Borkakati and Saikia, D. K. 2020. Insect Pests of Mustard and their Natural Enemies in Assam. Int.J.Curr.Microbiol.App.Sci. 9(07): 2785-2790.

doi: https://doi.org/10.20546/ijcmas.2020.907.328 